\title{
Influence of fire on critically endangered Swartland Shale Renosterveld in the Cape Floristic Region
}

\author{
Stephen R. Cousins ${ }^{1}$ (D) | Ed T. F. Witkowski ${ }^{2}$ | Karen J. Esler ${ }^{1,3}$
}

\author{
${ }^{1}$ Department of Conservation Ecology \\ and Entomology, Stellenbosch University, \\ Matieland, South Africa \\ ${ }^{2}$ School of Animal, Plant and Environmental \\ Sciences, University of the Witwatersrand, \\ Johannesburg, South Africa \\ ${ }^{3}$ Centre for Invasion Biology, Stellenbosch \\ University, Matieland, South Africa

\section{Correspondence} \\ Stephen R. Cousins, Department of \\ Conservation Ecology and Entomology, \\ Stellenbosch University, Matieland, South \\ Africa. \\ Email: swartland.botanics@gmail.com
}

\section{Funding information}

National Research Foundation NRF (South Africa), Grant/Award Number: 101300 and 103841; Botanical Education Trust (South Africa); Table Mountain Fund/Fynbos Forum (South Africa); Stellenbosch University (South Africa)

Co-ordinating Editor: Norbert Hölzel

\begin{abstract}
Questions: The degree to which renosterveld shrublands are fire-dependent is currently unclear. To address this issue, the following questions were asked: (1) does smoke stimulate germination of soil-stored seeds in renosterveld; (2) does recentlyburned renosterveld display changed composition and higher diversity than unburned vegetation; and (3) how do the species compositions of renosterveld soil seed banks and standing vegetation compare?
\end{abstract}

Location: Swartland, Cape Floristic Region, South Africa.

Methods: Soil seed bank samples from a north- and south-facing slope were smoketreated and germinated to test for smoke-stimulated germination. Burned standing vegetation was surveyed 16 months post-fire, as was unburned vegetation on the same slopes. Seed bank species richness and density were compared between smoketreated and untreated samples within and between slopes. Burned and unburned standing vegetation were compared within and between slopes in terms of species richness, abundance and aerial cover. Compositional similarity of the seed banks and standing vegetation was assessed.

Results: Seed banks were dominated by annuals and graminoids. Smoke treatment had no effect, except for driving significantly higher species richness and seedling density in south-facing slope perennial shrubs. Species richness and seedling density were significantly higher in seed banks on the south-facing slope compared to the northfacing slope. Burned standing vegetation exhibited significantly higher diversity than unburned vegetation. Annuals and graminoids displayed significantly higher species richness and aerial cover in burned renosterveld. The north-facing slope contained less than half the number of species $/ \mathrm{m}^{2}$ compared to the south-facing slope. The seed banks and standing vegetation showed low to intermediate similarity (Sørensen $=31 \%$ $53 \%$ ), but grouped close together on an NMDS plot, suggesting intermediate similarity overall.

Conclusions: Elevated germination of perennial shrubs in smoke-treated seed bank samples and increased diversity of post-fire standing vegetation suggest the renosterveld in this study shows elements of a fire-driven system. Certain species only recruited in burned sites, suggesting fire-stimulated germination. Aspect had a major influence on plant community composition, with the mesic south-facing slope being more diverse than the xeric north-facing slope. The similarity between the seed banks 
and standing vegetation was higher than previously shown for renosterveld, and appears to be higher than for fynbos.

\section{KEYWORDS}

burn, diversity, germination, heuweltjie, seed banks, shrubland, similarity, slope, smoke, species richness, standing vegetation

\section{1 | INTRODUCTION}

Fire is a key ecological driver in Mediterranean-type ecosystems, and many species therein exhibit fire-dependent reproduction, relying on cues such as heat and/or smoke to stimulate seed germination (Keeley, Bond, Bradstock, Pausas, \& Rundel, 2012). Fire-stimulated flowering (particularly in geophytes and graminoids) is also common in these systems (Keeley et al., 2012; Lamont \& Downes, 2011; Le Maitre \& Brown, 1992). In South Africa's Cape Floristic Region (CFR), fire plays a central role in determining major vegetation patterns, and regeneration in the region's fynbos shrublands is so strongly tied to fire that an estimated $90 \%$ of fynbos species recruit seedlings in the first 1-2 years post-fire (Keeley et al., 2012). Many of these species are serotinous, releasing their seeds after fire, with subsequent en masse germination (Le Maitre \& Midgley, 1992). Most other reseeding fynbos taxa rely on the germination of soil-stored seed for regeneration postfire (Holmes \& Newton, 2004). Persistent seed banks are especially important for species with life cycles that are shorter than the average fire cycle (Holmes \& Newton, 2004).

In the context of post-fire recovery in Mediterranean-type ecosystems, the soil seed bank represents a critical pool of regeneration potential (Hopfensperger, 2007). Seed banks have been studied in several Mediterranean-type ecosystems (Parker \& Kelly, 1989 and citations therein), and some studies have compared seed banks and the corresponding standing vegetation (Figueroa, Teillier, \& Jaksic, 2004; Heelemann, Krug, Esler, Reisch, \& Poschlod, 2013; Holmes \& Cowling, 1997; Valbuena \& Trabaud, 2001). Knowledge of the relationships between seed banks and the standing vegetation may be informative, especially for managing exotic species, planning for community responses to disturbances and restoring community diversity (Bossuyt \& Honnay, 2008; Hopfensperger, 2007). Communities that exhibit high similarity between the seed bank and standing vegetation are usually dominated by annuals and/or experience frequent disturbance (Dessaint, Chadoeuf, \& Barralis, 1997). Conversely, low similarity is observed in ecosystems where pioneer species emerge from persistent seed banks after disturbance, but do not become established years later because of shade-intolerance (Hopfensperger, 2007).

The Fynbos Biome of the CFR encompasses three major shrubland types: fynbos, renosterveld and strandveld. Fynbos is both fire-prone and fire-dependent, while renosterveld is fire-prone, but its fire dependency is unclear, and fires burn so rarely in strandveld that little is known about their impact (Keeley et al., 2012; Kraaij \& Van Wilgen, 2014). Often referred to as a "shrubby grassland" or "grassy shrubland", renosterveld is characterized by a predominantly evergreen shrub component, a mix of $\mathrm{C}_{3}$ and $\mathrm{C}_{4}$ grasses, and one of the most diverse assemblages of geophytes globally (Bergh, Verboom, Rouget, \& Cowling, 2014; Procheş, Cowling, Goldblatt, Manning, \& Snijman, 2006). Renosterveld primarily occurs in the fertile lowlands of the CFR, and contains a third of the region's endemic plant species (Rebelo et al., 2006). It is extremely variable across its range, with four recognized structural categories: shrubland, tussock grassland, grazing lawns and bulblands (Rebelo et al., 2006). Incorporating these categories are two broad types-lowland and mountain renosterveld-which comprise 30 sub-types that occur across various geologies, elevations and rainfall gradients (Rebelo et al., 2006). Due to its occurrence on nutrient-rich soils, lowland renosterveld has been dramatically reduced in extent by agricultural activities (Kemper, Cowling, \& Richardson, 1999; McDowell \& Moll, 1992). Currently $<10 \%$ of its original extent still exists, with the remaining remnants occurring as a severely fragmented system (Kemper et al., 1999; Newton \& Knight, 2005).

Despite renosterveld's global significance from a botanical and conservation perspective, its ecology is still poorly understood (Curtis, 2013). Fire and herbivory are considered the two main ecological drivers of the vegetation's structure and diversity, but their relative importance is unclear (Kraaij \& Van Wilgen, 2014). Renosterveld fire ecology is particularly under-researched, although new insights have been gained from recent studies (Curtis, 2013; Le Roux, 2011; Radloff, Mucina, \& Snyman, 2014; Van der Merwe \& Van Rooyen, 2011). Many renosterveld remnants are left unburned for extended periods (sometimes several decades), which in part, is possibly due to uncertainty around the fire-dependency of the vegetation type. A sound understanding of renosterveld fire ecology is important, for if certain species are fire-dependent, then the use of fire as a management tool for biodiversity conservation would be crucial (Curtis, 2013). Knowledge of renosterveld soil seed bank dynamics, and how they are influenced by fire, is central to understanding renosterveld fire ecology, and for developing restoration protocols for degraded vegetation.

In fynbos shrublands, species richness declines with increasing stand age post-fire (Bond \& Van Wilgen, 1996). Renosterveld is thought to be less fire-dependent than fynbos, given that renosterveld plant species generally do not display post-fire seed dispersal, nor do their seeds appear to exhibit smoke- or heat-stimulated germination (Kraaij \& Van Wilgen, 2014). Very old renosterveld stands may appear homogeneous and less productive, but there is little evidence to suggest that they reach senescence (Curtis, 2013). However, it appears that many reseeding shrubs in renosterveld only recruit post-fire (Curtis, 2013), and renosterveld may shift to a thicket state in the long-term absence of fire (and herbivory) (Bergh et al., 2014). 
Curtis (2013) demonstrated that recently-burned renosterveld in the Overberg exhibited higher species richness and abundance, as well as higher numbers of flowering geophytes and annuals than unburned vegetation. Similarly, Van der Merwe and Van Rooyen (2011) showed that the diversity of mountain renosterveld in the Roggeveld was highest 1-3 years post-fire and lowest after 9-10 years. An important consideration in addition to fire is that the Cape lowlands were also historically inhabited by large herds of megaherbivores (Krug, Krug, Midoko Iponga, Walton, \& Milton, 2004). Hence, it is possible that gap formation is not as closely tied to fire as it is in fynbos (which had less large mammal activity), since herbivory would have opened gaps to facilitate flowering and germination (Curtis, 2013). Krug et al. (2004) argued that herbivory was the primary driver of diversity in renosterveld, with fire playing a lesser role.

As with renosterveld's fire ecology, its soil seed banks have only recently started to receive attention from researchers (Cowan \& Anderson, 2014; Heelemann et al., 2013). In an investigation of intact and degraded renosterveld soil seed banks and standing vegetation, Heelemann et al. (2013) showed that several native species that emerged from smoke-treated soil samples exhibited significantly higher germination compared with untreated control samples. However, while larger numbers of seedlings appeared in the smoke treatment, this was only significant for certain sites, and there was little difference between the species composition of treated and untreated samples (Heelemann et al., 2013). These findings, as well as those from a study by Cowan and Anderson (2014), which showed no influence of fire cues on soil seed bank germination, suggest that fire has a minimal effect on renosterveld seed germination. It is also possible that there is geographic variation in response to fire, depending on the specific renosterveld sub-type in question.

There is a need for a deeper understanding of renosterveld fire ecology and soil seed banks in order to implement effective management interventions to conserve and restore remaining renosterveld remnants. Hence, the aim of this study was to investigate the influence of fire on standing vegetation and soil seed banks in Swartland Shale Renosterveld, a critically endangered lowland renosterveld type. Specifically, the following questions were asked: (1) does smoke act as a germination cue for soil-stored seeds in renosterveld; (2) does recently-burned renosterveld exhibit changed composition and higher plant diversity than unburned (climax) renosterveld; and (3) how similar is the species composition of renosterveld soil seed banks to that of the corresponding standing vegetation?

\section{2 | METHODS}

\section{1 | Study area and vegetation}

The study was conducted on the Porseleinberg, east of Malmesbury in the Swartland, Western Cape Province, South Africa (Appendix S1). The Porseleinberg harbours one of the largest remaining remnants of Swartland Shale Renosterveld (SSR). Three adjacent slopes of different aspect (north-, south- and east-facing) were selected for sampling, the altitudes of which ranged from ca. $320-380 \mathrm{~m}$. Fieldwork was confined to a single site as the study was dependent on the availability of recently-burned vegetation, which was only present at this site, where a prescribed burn had been conducted. The Swartland has a typical Mediterranean-type climate, with hot, dry summers and cool, wet winters. Malmesbury has a mean annual precipitation of $374 \mathrm{~mm}$ and mean monthly minimum and maximum temperatures of 10.4 and $24.8^{\circ} \mathrm{C}$, respectively. The predominant land use in the area is intensive agriculture-primarily winter cereals such as wheat and oats.

Swartland Shale Renosterveld is defined as a low to moderately tall leptophyllous shrubland of varying canopy cover, as well as low, open shrubland dominated by the shrub Elytropappus rhinocerotis (renosterbos; Rebelo et al., 2006). Earth mounds, known locally as heuweltjies, are a prominent feature of the landscape (Rebelo et al., 2006). While their origin and age remains controversial (Cramer, Von Holdt, Khomo, \& Midgley, 2016), their formation is commonly thought to be due to faunal activities (primarily termites and fossorial rodents) that result in soil translocation towards the mounds (Moore \& Picker, 1991). The soil characteristics of heuweltjies are often distinct, with vegetation that differs markedly from the surroundings (Knight, Rebelo, \& Siegfried, 1989; Midgley \& Musil, 1990). Stunted trees and thicket species in the genera Euclea, Olea and Searsia are often associated with heuweltjies (Rebelo et al., 2006).

\section{2 | Soil seed banks}

Soil seed bank sampling was conducted in unburned ( $>15$ years since previous fire) renosterveld on a north- and south-facing slope (Appendix S2). On each slope, ten $5 \times 5 \mathrm{~m}$ plots were established, and 20 soil samples (sample volume $=125 \mathrm{~cm}^{3}$; depth $=5 \mathrm{~cm}$, surface area $=25 \mathrm{~cm}^{2}$ ) were removed using a soil corer from equally spaced sampling points within each plot, including both open and below-canopy microhabitats. Sampling was conducted in Mar 2016, at a time when the seed bank was dormant. Since the north-facing slope had several clearly distinguishable heuweltjies, five plots were placed within the heuweltjies and five in the inter-heuweltjie matrix. (The south-facing slope had no obvious heuweltjies.) The soil samples taken from each plot were pooled, placed in brown paper bags and stored under ambient conditions until further processing.

Directly prior to the germination trials, the soil samples were sieved with a 10-mm mesh sieve to remove any large stones, litter and underground storage organs of geophytes, as the focus was to test specifically for smoke-stimulated seed germination. The 20 pooled soil samples from each plot were divided into two equal soil volumes, each of which was transferred into a labelled seedling tray (i.e. 10 samples/tray). A layer of sterile sand was placed under the soil, with a lining of fine gauze at the bottom of the tray to prevent the soil from washing out. There was a total of 20 trays/slope, ten of which were smoke-treated and the other ten untreated (hence 40 trays altogether). For the smoke treatment, the method successfully used for smoke-stimulated germination of the seeds of various fynbos species by De Lange and Boucher (1990) and Brown (1993) was employed. A mixture of approximately $2 \mathrm{~kg}$ of fresh renosterveld leaf and stem material was burned in a metal drum and the smoke channelled into a 
tent (ca. $4.0 \times 1.5 \times 1.0 \mathrm{~m}$ ) in which the seedling trays containing the soil samples were placed. The trays were left in the tent for $3 \mathrm{hr}$ to allow the smoke particles to settle, after which all the soil samples were watered till the soil surface was flooded. The trays were placed in a greenhouse at Stellenbosch University, watered daily using an automated overhead irrigation system, and inspected weekly for germination for 27 weeks from Apr to Oct 2016. Germinated seedlings were allowed to grow until positive identifications could be made, following which they were removed from the trays.

\subsection{Survey of burned and unburned standing vegetation}

A vegetation survey on three slopes of different aspect (north-, southand east-facing) was conducted 16 months after a prescribed burn on parts of the south- and east-facing slopes (Appendix S2). Sampling was done in spring (Aug and Sept 2016) at a time when all the plant species in the system were most apparent. The north- and south-facing slopes were the same as those sampled for the soil seed bank study. Sampling of the unburned vegetation on the south- and east-facing slopes took place after the burn, but in patches that had not burned. These patches were not considered to be markedly different from the burned areas in terms of fire-proneness.

Six $10 \times 10 \mathrm{~m}$ plots were erected on the south-facing slope, three each in the burned and unburned areas. On the north-facing slope (unburned), eight $5 \times 5 \mathrm{~m}$ plots were marked out to sample the heuweltjie patches and inter-heuweltjie matrix (four plots each), as the heuweltjies were too small to accommodate $10 \times 10 \mathrm{~m}$ plots. Four $10 \times 10 \mathrm{~m}$ plots were also marked out on the east-facing slope, two each in the burned and unburned areas. The burned area on this slope was relatively small, and could only accommodate a limited number of plots compared to the other slopes. In the $10 \times 10 \mathrm{~m}$ plots, ten $1-\mathrm{m}^{2}$ quadrats were placed at regular intervals along the perimeter, with a $1 \mathrm{~m}$ buffer zone between quadrats and the borders of the plot, while five $1-\mathrm{m}^{2}$ quadrats were sampled in the $5 \times 5 \mathrm{~m}$ plots. In each quadrat, the presence of all vascular plant species was recorded, and for each species, visual estimates were made of the number of individuals and percentage aerial cover. Upon completion of quadrat sampling, the remainder of each plot was searched for any additional species not encountered in the quadrats. The presence of these species was noted, and they were included in the overall species list, but their abundance and cover were not estimated.

\section{4 | Species identifications}

Identification of the species in the soil seed banks and standing vegetation was done using relevant field guides and species descriptions in Manning and Goldlatt (2012). Species were assigned to one of six growth form categories as per the designations in Manning and Goldlatt (2012). Pressed specimens were made for taxa that were not identifiable in the field, and these were compared with herbarium material at the Tygerberg and Compton herbaria in Cape Town and/or shown to expert botanists to confirm identifications where necessary.
Specimens were identified to species or at least genus level, but where this was not possible (e.g. due to the absence of flowers or fruits), individuals of similar morphology were grouped together into "morphospecies" and their growth form noted (14\% of specimens).

\section{5 | Data analysis}

Following tests for normality, one-way ANOVAs and LSD post-hoc tests were used to test for differences in (1) abundance (number of individuals $/ \mathrm{m}^{2}$ ) for burned and unburned standing vegetation, as well as smoke-treated and untreated soil seed bank samples; (2) species richness (number of species/tray for soil seed banks and per $\mathrm{m}^{2}$ for the standing vegetation); and (3) aerial cover of the six growth form categories (burned and unburned vegetation on the south- and eastfacing slopes combined, and the unburned north-facing slope). Species richness is presented per tray, since unlike plant density, it cannot be extrapolated from the level of an individual tray to the square metre since the species-area relationship is non-linear. Differences in species richness, abundance and aerial cover within growth form categories were analysed using paired $t$-tests (smoke-treated vs. untreated soil seed banks) and unpaired $t$-tests (burned vs. unburned or heuweltjie vs. inter-heuweltjie for the standing vegetation). An ANOSIM (ANAlysis Of SIMilarity) and NMDS were conducted in Primer $\vee 7$ (Quest Research, Massey University, Auckland, New Zealand) to assess the compositional similarity of the soil seed banks and standing vegetation (north- and south-facing slopes only). For both analyses, the species abundance data were transformed to presence/absence since the unit area sampled for the seed banks and standing vegetation differed. The diversity indices were calculated using EstimateS v 9. All other statistical analyses were conducted in Statistica $\vee 13$ (Dell, Tulsa, OK, USA).

\section{3 | RESULTS}

\subsection{Soil seed bank experiment}

The soil seed bank samples yielded a total of 10,578 seedlings, with the south-facing slope containing five times the number of individuals as the north-facing slope (smoke-treated and untreated samples combined; Table 1). Seedling density differed between slopes, while within slopes, only untreated samples from heuweltjies on the north-facing slope contained significantly more seedlings than inter-heuweltjie samples $\left(F_{7,52}=21.71, p<.0001\right.$; Table 1$)$. The south-facing slope yielded a total of 75 species compared to 57 from the north-facing slope (smoke-treated and untreated combined), with a total of 108 species for both slopes together. (A full species list for the seed banks and standing vegetation appears in Appendix S3.) Overall species richness of smoke-treated and untreated samples within slopes was approximately equal ( 60-south and $\sim 50-$ north). The number of species per tray was significantly higher for samples from the southfacing slope (both treated and untreated: 20-22 species, than the north, heuweltjie and inter-heuweltjie samples combined: $12-13$ species; $F_{7,52}=11.31, p<.0001 ;$ Table 1). Within slopes there were no 


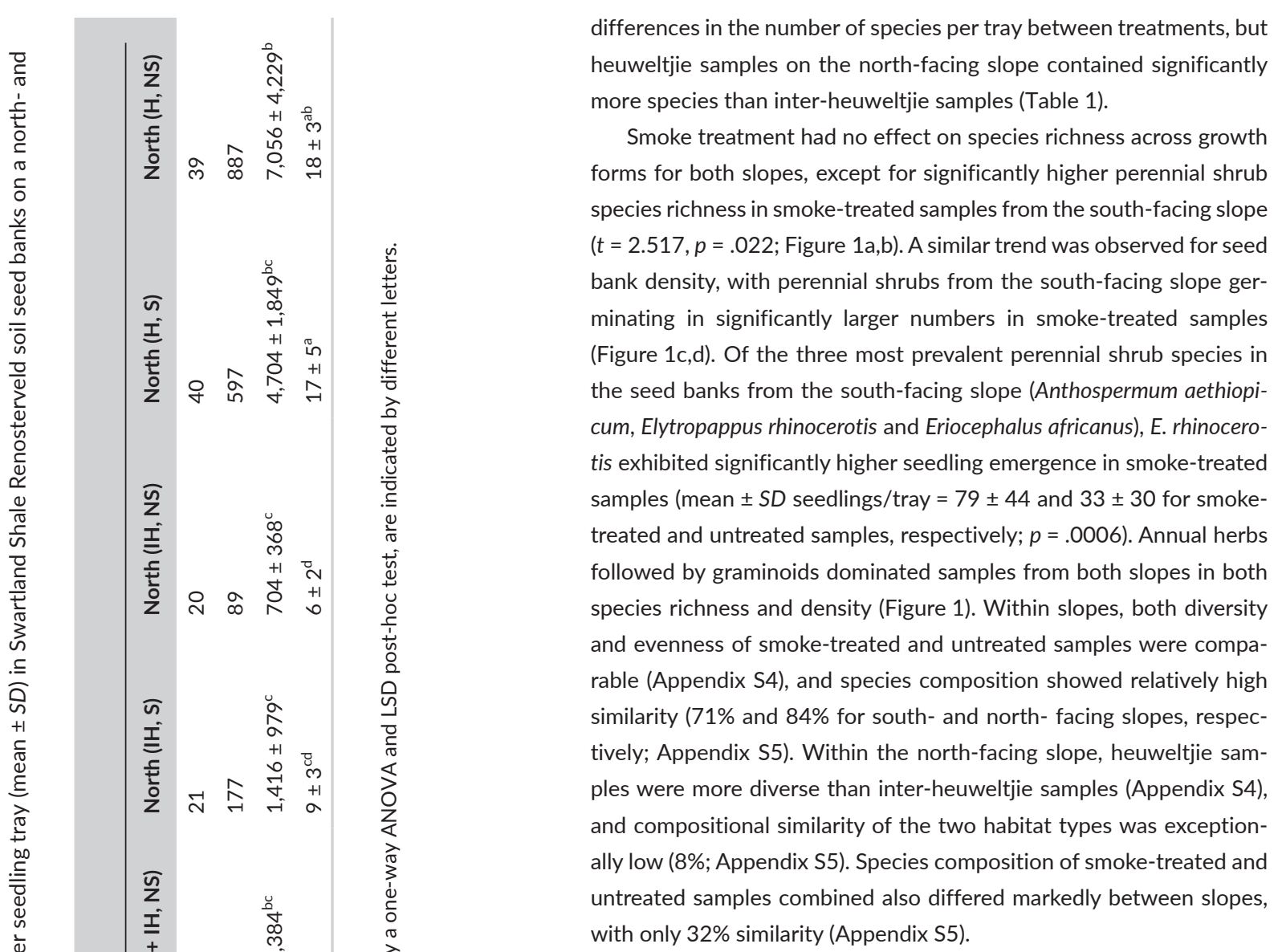

\subsection{Standing vegetation}

Number of species $/ \mathrm{m}^{2}$ differed significantly both within and between the north- and south-facing slopes $\left(F_{4,135}=75.34, p<.0001\right.$; Table 2$)$. Burned areas on the south-facing slope displayed significantly higher species richness than the unburned areas (means $21 \pm 5$ and $16 \pm 4$ species $/ \mathrm{m}^{2}$, respectively), and more than double the species richness on the north-facing slope ( $8 \pm 3$ species; Table 2$)$. Up to 31 species $/ \mathrm{m}^{2}$ were recorded in the burned parts of the south-facing slope, while the maximum for the north-facing slope was 14 species $/ \mathrm{m}^{2}$. Heuweltjie patches on the north-facing slope exhibited significantly higher species richness than the inter-heuweltjie matrix ( $9 \pm 3$ vs. $6 \pm 2$ species/ $\mathrm{m}^{2}$ ). Plant density differed significantly within and between slopes $\left(F_{4,135}=26.84, p<.0001\right.$; Table 2$)$. Burned tracts of the south-facing slope displayed more than double the plant density of the unburned portions, and on the north-facing slope, the plant density in the heuweltjie patches was five-fold higher than in the inter-heuweltjie matrix (Table 2).

For the south- and east-facing slopes combined, annuals and graminoids both showed higher species richness and aerial cover in the burned vegetation, while perennial shrub species richness and cover were higher in the unburned vegetation (Figures $2 \mathrm{a}$ and 3, Appendix S6). The density of both annuals and perennial shrublets was higher in the burned than the unburned vegetation (Figure $2 b$ ). On the northfacing slope, heuweltjies displayed significantly higher cover of annuals, geophytes and graminoids, while perennial shrub cover was higher 

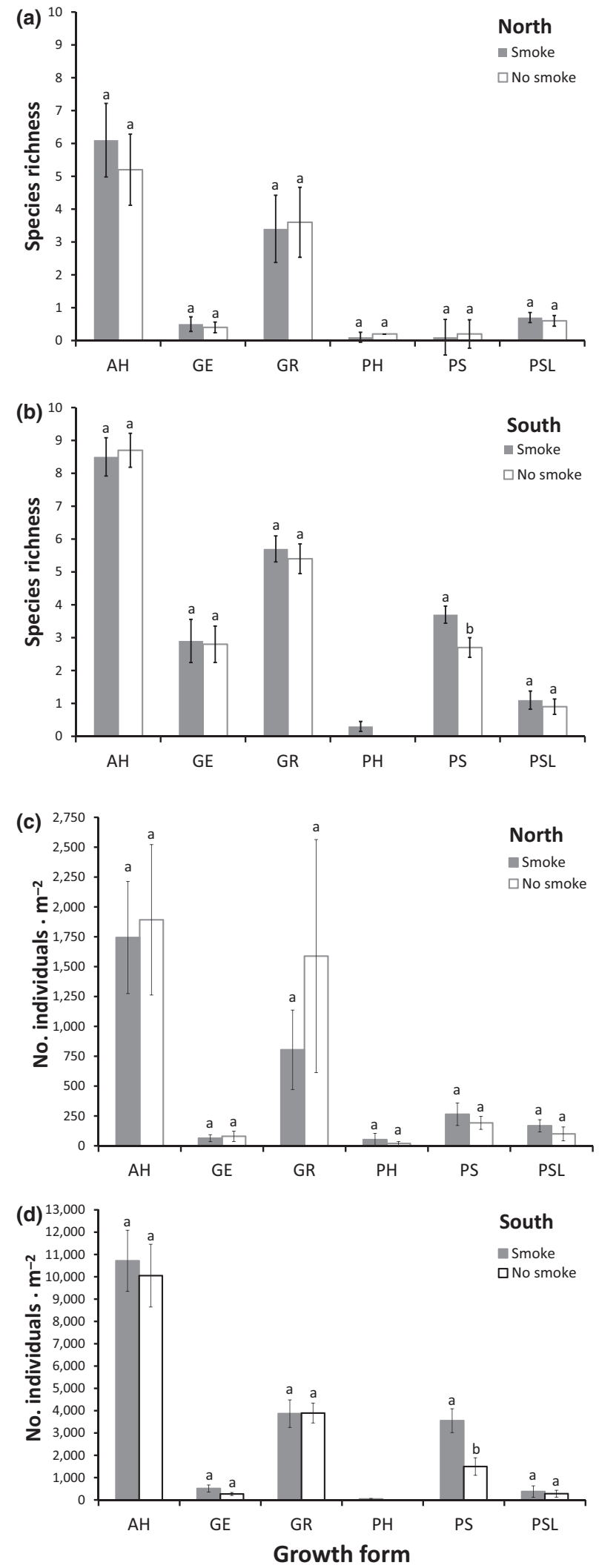

in the inter-heuweltjie matrix (Figure 3b). The south-facing slope (both burned and unburned) had significantly higher graminoid cover than the north-facing slope, while the opposite was true for perennial shrub
FIGURE 1 Species richness/seedling tray and seedling density (No. individuals $/ \mathrm{m}^{2}$ ) (mean $\pm S E$ ) for soil seed banks from unburned Swartland Shale Renosterveld on a north-facing slope (a and c) and a south-facing slope (b and d). AH, Annual herbs; GE, Geophytes; GR, Graminoids; PH, Perennial herbs; PS, Perennial shrubs and PSL, Perennial shrublets. Each tray is equivalent to a soil volume of approximately $1,250 \mathrm{~cm}^{3}$ and $250 \mathrm{~cm}^{2}$ of soil surface area, sampled to a depth of $5 \mathrm{~cm}$. Different letters indicate significant differences within growth forms between smoke-treated and untreated samples using paired $t$-tests at $p<.05$

cover (Figure 3c). Burned renosterveld exhibited higher diversity than unburned renosterveld (Appendix S4). Both burned and unburned vegetation on the south- and east-facing slopes displayed higher diversity than that of the north-facing slope (Appendix S4). The compositional similarity of burned and unburned renosterveld was intermediate ( 60\%), with the former containing 1.4-1.6 times the number of unique species found in the latter (Appendix S5). Burned and unburned vegetation on the south-facing slope grouped close together, but separately on the NMDS plot (Figure 4). Unburned renosterveld on the north- and south-facing slopes showed very low similarity (25\%; Appendix S5) and formed separate groupings on the NMDS plot (Figure 4).

\section{3 | Soil seed bank and standing vegetation comparison}

The species composition of the soil seed banks and standing vegetation differed between slopes and treatments (Global $\mathrm{R}_{\text {ANOSIM }}=0.829$, $p<.001$ ). Of the 45 pair-wise ANOSIM comparisons (within and between the seed banks and standing vegetation), 42 showed significant dissimilarity, with each pair having an $\mathrm{R}_{\text {ANOSIM }}>0.3$ and $p<.02$. The only three comparisons that showed no significant dissimilarity $\left(R_{\text {ANOSIM }}<0.1, p>.2\right)$ were within the soil seed banks: (1) south-facing slope (smoke-treated vs. untreated), (2) north-facing slope, interheuweltjie (smoke-treated vs. untreated), and (3) north-facing slope (heuweltjie smoke-treated vs. untreated). The standing vegetation on the south-facing slope (both burned and unburned) showed relatively low compositional similarity with both smoke-treated and untreated soil seed bank samples (Sørensen similarity coefficient $=38 \%-44 \%$; Appendix S5). Notwithstanding, both seed bank treatments formed a tight cluster within the burned standing vegetation on the same slope on the NMDS plot (Figure 4). Likewise, the soil seed banks and unburned standing vegetation on the north-facing slope displayed intermediate similarity (42\%-53\%), but heuweltjie and inter-heuweltjie seed bank samples clustered relatively close to the corresponding standing vegetation on the NMDS plot, especially the inter-heuweltjie samples (Figure 4).

\section{4 | DISCUSSION}

This study contributes to a growing body of research on the role of fire in renosterveld and Mediterranean-type climate ecosystems as 


\begin{tabular}{llllll} 
& \multicolumn{3}{l}{ Slope and treatment } & & \\
\cline { 2 - 6 } & South (B) & South (UB) & $\begin{array}{l}\text { North } \\
(\mathrm{H}+\mathrm{IH}, \mathrm{UB})\end{array}$ & $\begin{array}{l}\text { North } \\
(\mathrm{H}, \mathrm{UB})\end{array}$ & North (IH, UB) \\
\hline Species richness (S) & 92 & 79 & 63 & 44 & 32 \\
No. individuals $/ \mathrm{m}^{2}$ & $282 \pm 11^{\mathrm{a}}$ & $131 \pm 57^{\mathrm{bc}}$ & $86 \pm 105^{\mathrm{b}}$ & $143 \pm 122^{\mathrm{c}}$ & $28 \pm 32^{\mathrm{d}}$ \\
No. species $/ \mathrm{m}^{2}$ & $21 \pm 5^{\mathrm{a}}$ & $16 \pm 4^{\mathrm{b}}$ & $8 \pm 3^{\mathrm{cd}}$ & $9 \pm 3^{\mathrm{c}}$ & $6 \pm 2^{\mathrm{d}}$ \\
$\begin{array}{l}\text { No. species } / \mathrm{m}^{2} \\
\text { (range) }\end{array}$ & $7-31$ & $10-26$ & $3-14$ & $3-14$ & $3-11$ \\
\hline
\end{tabular}

TABLE 2 Species richness, plant density (number of individuals $/ \mathrm{m}^{2}$ ) and number of species $/ \mathrm{m}^{2}$ (mean $\pm S D$ ) in Swartland Shale Renosterveld standing vegetation on a north- and south-facing slope

B, burned; UB, unburned; $\mathrm{H}$, heuweltjie; IH, inter-heuweltjie matrix.

Significant differences in (a) plant density and (b) number of species $/ \mathrm{m}^{2}$, determined by one-way ANOVA and LSD post-hoc test, are indicated by different letters.

a whole. The results of the study are congruent with previous studies (Curtis, 2013; Le Roux, 2011; Van der Merwe \& Van Rooyen, 2011) that suggest that fire is an important part of renosterveld ecology, but its effects on the vegetation type are not as clear cut as in fynbos shrublands. While smoke-treating the seed banks did not have a marked effect on species composition and seedling density, there was a significant response in the perennial shrub component, suggesting that smoke may be important for stimulating germination in this group. Burning the standing vegetation resulted in significant increases in the species richness and cover of annual and graminoid growth forms, and burned renosterveld displayed higher overall diversity than unburned vegetation. Slope aspect had a major influence on plant community composition, with the mesic south-facing slope being more diverse than the xeric northfacing slope. Significant differences between heuweltjie and interheuweltjie patches in terms of species composition, cover and abundance highlight the contribution of these localized habitats to the spatial heterogeneity of renosterveld. The soil seed banks and standing vegetation showed a fair degree of similarity, and appear to exhibit less dissimilarity than fynbos shrublands.

\section{1 | Soil seed banks}

Seed density $\left(3,880-19,116\right.$ seeds $\left./ \mathrm{m}^{2}\right)$ compared well with pristine renosterveld in a previous study on SSR (4,948-15,634 seeds/ $\mathrm{m}^{2}$; Heelemann et al., 2013). These seed densities are substantially higher than those found for other Mediterranean-type shrublands, e.g. mountain fynbos $\left(1,100-1,900\right.$ seeds $/ \mathrm{m}^{2}$; Holmes \& Cowling, 1997) and Chilean matorral (325-678 seeds $/ \mathrm{m}^{2}$, Jiménez \& Armesto, $1992 ;<1,000-11,000$ seeds $/ \mathrm{m}^{2}$, Figueroa et al., 2004). It appears that smoke is not a major germination cue for renosterveld seeds, as only the perennial shrub component from the south-facing slope showed a significant smoke-stimulated germination response. Similarly, Heelemann et al. (2013) and Cowan and Anderson (2014) showed that smoke treatment had minimal to no effect on the germination of renosterveld seed banks. The elevated seedling density observed in the perennial shrub component in the smoke-treated samples in the present study was strongly influenced by Elytropappus rhinocerotis, as the number of seedlings of this species that germinated in the smoke-treated soil samples was almost 2.5 times that in the untreated samples. This apparent smoke-stimulated germination is supported by observations made in a study by Levyns (1956), which reported elevated germination of $E$. rhinocerotis in burned vegetation plots compared to cleared and unburned plots. However, from an ecological perspective, smoke-stimulated germination cannot always be assumed to indicate fire-dependency, as significantly enhanced germination in smoke-treated seeds of plant species from non-fire-prone vegetation types also occurs (Pierce, Esler, \& Cowling, 1995).
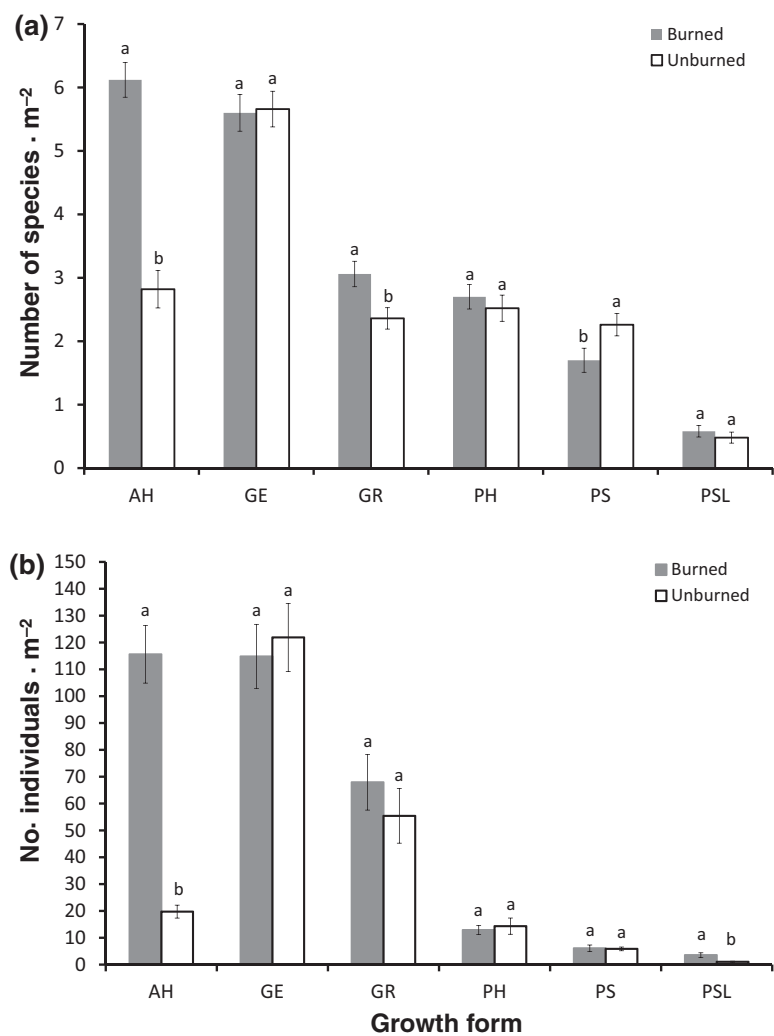

FIGURE 2 (a) Species richness and (b) plant density (mean \pm SE) of growth forms in burned (16 months postfire) versus unburned Swartland Shale Renosterveld standing vegetation on a south- and east-facing slope combined. AH, Annual herbs; GE, Geophytes; GR, Graminoids; PH, Perennial herbs; PS, Perennial shrubs and PSL, Perennial shrublets. Different letters indicate significant differences between treatments within growth forms using unpaired $t$-tests $(p<.05)$ 

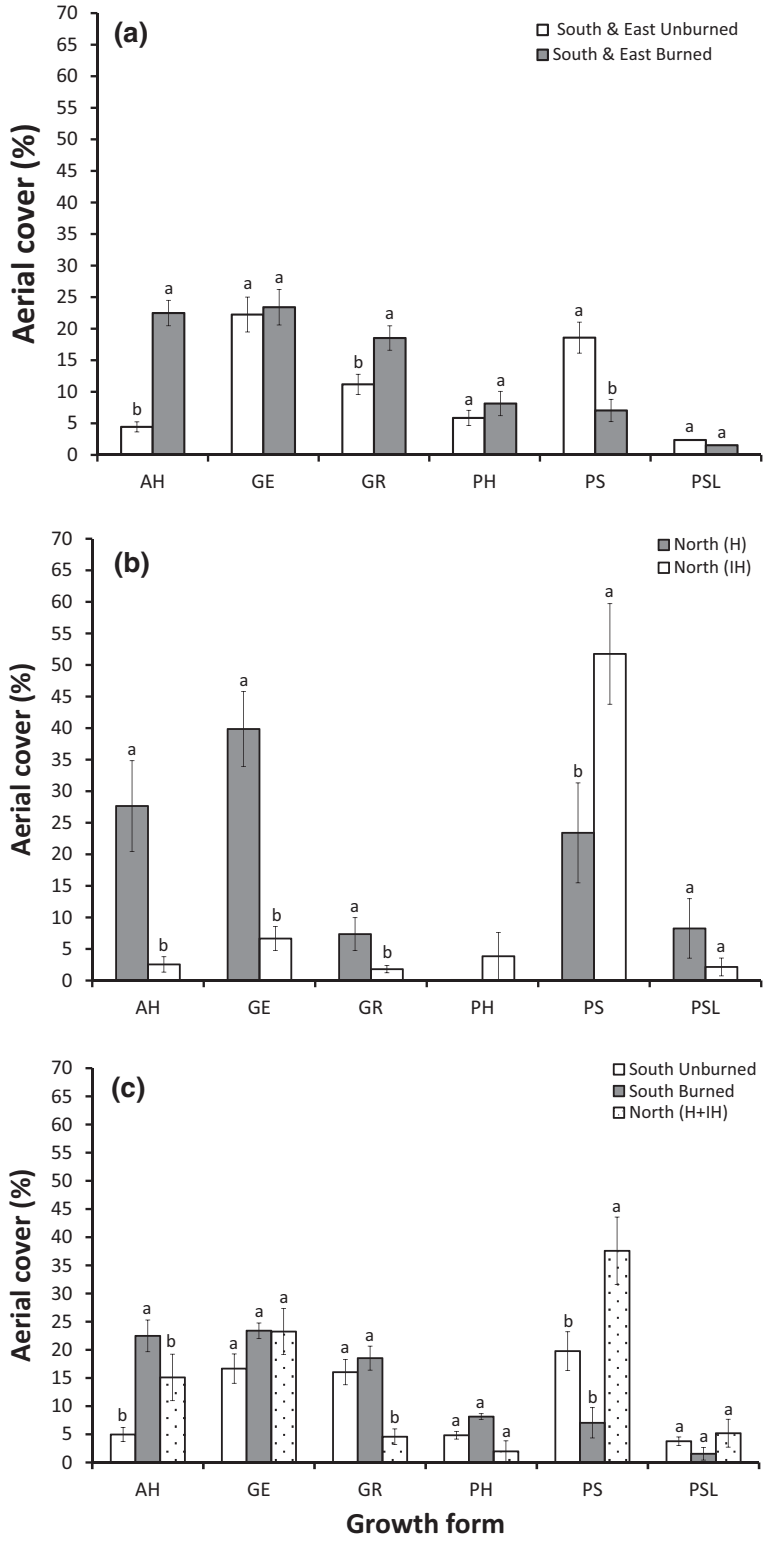

FIGURE 3 Aerial cover of six growth forms of Swartland Shale Renosterveld standing vegetation on (a) a south and east-facing slope combined (burned vs. unburned), (b) a north-facing slope (heuweltjies vs. interheuweltjies), and (c) a north-facing slope $(\mathrm{H}$, heuweltjies and $\mathrm{IH}$, Inter-heuweltjie matrix, combined) and a south-facing slope (burned and unburned). AH, Annual herbs; GE, Geophytes; GR, Graminoids; PH, Perennial herbs; PS, Perennial shrubs and PSL, Perennial shrublets. Different letters indicate significant differences between slopes and/or treatments within growth forms using a t-test $(p<.05)$ for (a) and (b) and one-way ANOVA with Post-hoc Tukey HSD test $(p<.05)$ for $(c)$

It is possible that further enhancement of germination in the soil seed banks could have been obtained following heat treatment in addition to the smoke treatment, as heat has been shown to improve germination in certain species from other Mediterranean-type shrublands (Bell, Plummer, \& Taylor, 1993; Hall, Newton, Holmes, Gaertner, \& Esler, 2016; Keeley \& Bond, 1997; Moreira, Tormo, Estrelles, \& Pausas, 2010; Reyes \& Trabaud, 2009). These species tend to have hard, impermeable seed coats which are cracked by heat, thus breaking physical dormancy-a phenomenon commonly observed in many species in the Fabaceae (Cocks \& Stock, 1997; Herranz, Ferrandis, \& Martínez-Sánchez, 1998). Further renosterveld soil seed bank experiments that include heat treatments and/ or germination experiments on the seeds of a range of renosterveld plant species using heat and smoke treatments will help to elucidate the role of fire-related cues in stimulating seed germination in renosterveld.

\section{2 | Standing vegetation}

The increased diversity of post-fire renosterveld in this study agrees with similar trends observed in renosterveld elsewhere, e.g., Roggeveld mountain renosterveld (Van der Merwe \& Van Rooyen, 2011) and Overberg lowland renosterveld (Curtis, 2013). Other Mediterranean-type shrublands such as fynbos and chaparral also exhibit elevated diversity post-fire (Bond \& Van Wilgen, 1996; Keeley, Fotheringham, \& Baer-Keeley, 2005). In chaparral, more than half the flora may comprise post-fire annuals, which are present between fires only as dormant seeds (Keeley, 1992). In contrast, the renosterveld examined in this study did not appear to contain a large, strictly post-fire annual component, as most of the annuals present in the burned vegetation were also found in the adjacent unburned areas, although in smaller numbers. The vegetation survey was conducted in the second spring post-fire, and the preponderance of annuals did not appear to result from en masse fire-stimulated germination. Despite similar climatic conditions during both the first and second spring seasons post-fire, the cover and abundance of annuals in the first spring were substantially lower, although this was not determined statistically. It is likely that the combustion of the shrub component created gaps for the annuals to colonize during the second winter/spring after setting seed in the first spring/summer after the burn. Hence, the profusion of annuals and grasses was probably due to their mass recruitment only in the second spring post-fire. Fynbos shrublands show a similar increase in the canopy cover of annuals over the first few years post-fire (Rutherford, Powrie, Husted, \& Turner, 2011). For renosterveld annuals and grasses, and possibly all other species that did not appear to show direct fire-stimulated germination, it appears that any gapforming disturbance may be sufficient to promote recruitment and subsequent flowering.

Renosterveld contains a large proportion of reseeders, and vegetation surveys after experimental burns in Overberg renosterveld revealed that most of the dominant reseeders recruited in burned stands but not in unburned vegetation (Curtis, 2013). Dominant reseeding shrubs in SSR e.g., Dodonaea viscosa, Elytropappus rhinocerotis, Passerina truncata, Pteronia divaricata and Wiborgia tetraptera also seldom recruit in older stands (if at all), while Eriocephalus africanus does (S.R. Cousins, pers. obs.). Although the lifespans of these dominant reseeders appear to be in the order of decades, it is uncertain how long the standing vegetation can remain unburned until these species eventually senesce and their seed banks lose 


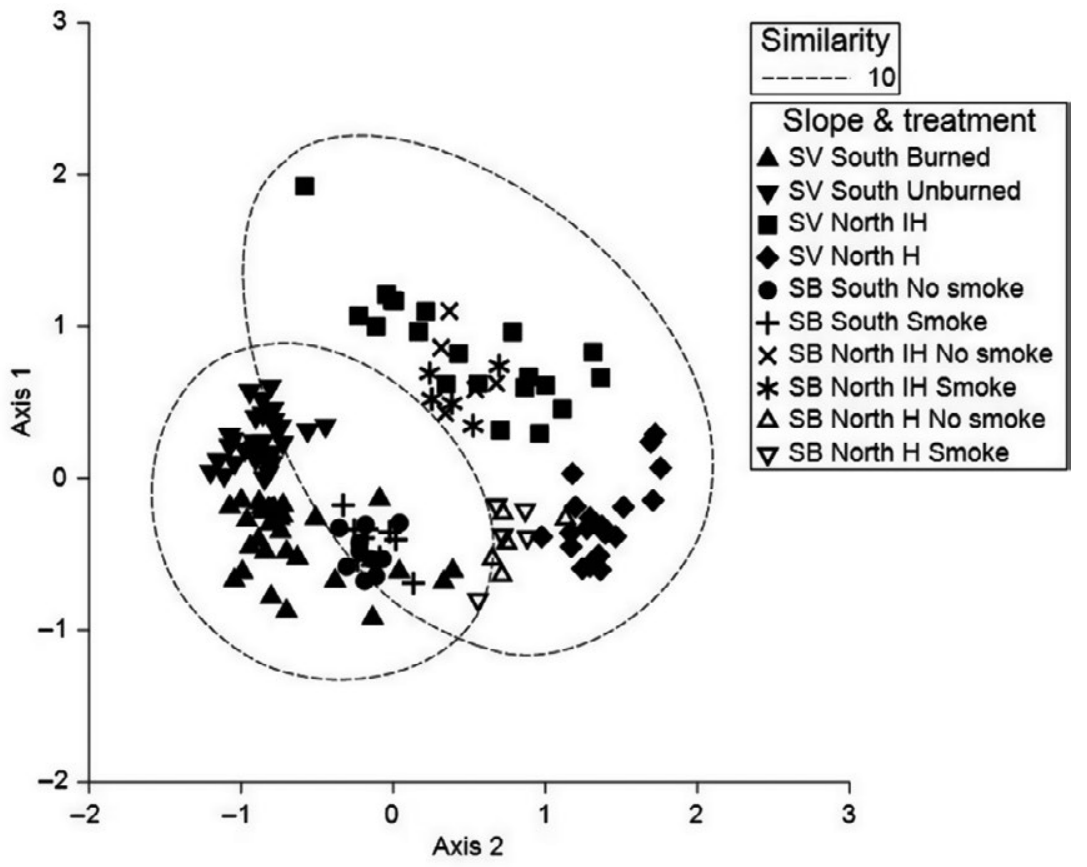

FIGURE 4 Nonmetric Multidimensional Scaling (NMDS) plot showing the relationship between Swartland Shale Renosterveld standing vegetation (SV) and soil seed banks (SB) on a south facing slope (burned and unburned) and a north-facing slope (unburned only; IH, inter-heuweltjie matrix; $\mathrm{H}$, heuweltjies). The symbols represent the $1 \mathrm{~m}^{2}$ quadrats sampled in the standing vegetation, and the seedling trays for the soil seed bank experiment. Samples with a resemblance score (similarity) of 10 are grouped together within the convex hulls, which provided the best fit. The species abundance data were transformed to presence/absence and the $2 \mathrm{D}$ stress value is 0.14 viability. Dodonaea viscosa responded positively to the burn in this study, as it only occurred as large mature individuals in the unburned vegetation, while numerous seedlings were recorded in the adjacent burned areas. This species produces dormant seeds that have a water-impermeable seed coat, and therefore require scarification or heat shock to overcome physical dormancy (Baskin, Davis, Baskin, Gleason, \& Cordell, 2004). However, D. viscosa is also known to recruit in abandoned agricultural fields where fire is excluded (S.R. Cousins, pers. obs.). In contrast to these long-lived perennial shrubs, certain renosterveld species appear to be absent from the standing vegetation in older stands, only existing in the soil seed bank. Two such species featured prominently in the burned areas in this study, but were not found in adjacent unburned vegetation (Indigofera incana and Hermannia alnifolia). It would appear that firerelated stimuli induced germination in both species, as heat shock is known to act as a germination cue in both genera (Hassen, Pieterse, \& Rethman, 2004; Keeley \& Bond, 1997).

\section{3 | Soil seed bank-standing vegetation comparison}

Despite the similarity index and ANOSIM results showing low to intermediate similarity between the soil seed banks and standing vegetation, they did group together within their respective slopes on the NMDS plot, indicating a fair degree of overlap in terms of species composition. In contrast, a similar study by Heelemann et al. (2013) showed that SSR seed banks grouped separately from the corresponding standing vegetation, indicating low similarity between the two. Holmes and Cowling (1997) demonstrated that fynbos seed banks are highly dissimilar to the standing vegetation, since the soil seed banks are characterized by a preponderance of post-fire ephemerals, while serotinous and resprouting species dominate the standing vegetation. Serotinous shrub seeds are held in the canopy and therefore do not enter the soil seed bank (Holmes \& Cowling, 1997). A higher degree of similarity between seed banks and standing vegetation would be expected for renosterveld compared to fynbos, as serotinous species are uncommon in renosterveld, although resprouting taxa are well represented. Interestingly, the soil seed banks from the south-facing slope in this study grouped within the burned standing vegetation in the NMDS plot, suggesting that the disturbance created by the fire had a similar effect to the disturbance that occurred by removing and sieving the soil samples (i.e. favouring annuals-a group that responds well to disturbance in plant communities in general; McIntyre, Lavorel, Landsberg, \& Forbes, 1999).

The two growth forms that were poorly represented in the seed banks were geophytes and perennial herbs. Geophytes form a large component of renosterveld flora, so they might be expected to feature prominently in the seed banks. However, many reproduce both vegetatively and sexually, and hence produce far less seeds per plant than annuals, graminoids and reseeding perennial shrubs, which primarily or exclusively reproduce sexually, and hence dominate the seed bank. Resprouting shrubs and shrublets such as Asparagus rubicundus, Cissampelos capensis, Montinia caryophyllacea, Salvia africana-caerulea, Searsia spp. and Solanum guineense were absent from the seed banks, although they were also less common in the standing vegetation than reseeding shrubs. Seed production in resprouters is much lower than in reseeders, and hence they have also been shown to occur sparsely in fynbos seed banks (Holmes \& Cowling, 1997). The poor representation of perennial herbs in the seed bank is also possibly related to lower seed production in this group compared to annuals, graminoids and reseeding shrubs. 
A striking finding was the effect of aspect on the composition of both the standing vegetation and the seed bank. This was not an unexpected observation, but is something that does not feature prominently in the renosterveld literature. The species richness in the unburned areas on the more mesic south-facing slope was approximately double that on the comparatively xeric north-facing slope. Sternberg and Shoshany (2001) also showed that aspect had significant effects on the composition, structure and density of the plant communities in woody formations in two climatological regions in the Mediterranean. Similarly, in Chilean matorral, aspect strongly influences mesoclimatic conditions, with marked differences in the vegetation on equator-ward and poleward slopes (Badano, Cavieres, Molina-Montenegro, \& Quiroz, 2005). However, in contrast to the renosterveld in this study, diversity of the matorral was higher on the xeric slopes (Badano et al., 2005).

\section{4 | Implications for management}

Many renosterveld remnants on private property remain unburned for extended periods, probably partly because the necessity for them to burn has been uncertain, and because landowners are reluctant to implement prescribed burns due to the risks involved. The results from this study, along with a growing body of research on fire in renosterveld, suggest that fire is an important ecological driver in the vegetation type, although its effects are not as clearcut as in fynbos. Prescribed burning at appropriate intervals (which may vary depending on the specific renosterveld type in question) is likely to promote diversity in renosterveld. However, it appears that for renosterveld occurring on hillsides, not all slopes may be equally fire-prone, and fire return intervals may be longer on drier north-facing slopes that contain a large succulent component and possibly take longer to accumulate biomass. On-going research on renosterveld fire ecology is vital for making science-based management decisions that ensure the continued persistence of species in renosterveld remnants.

\section{ACKNOWLEDGEMENTS}

We thank the National Research Foundation NRF (South Africa) (Grant nos 101300 and 103841), the Botanical Education Trust (South Africa), Table Mountain Fund/Fynbos Forum (South Africa) and Stellenbosch University (South Africa) for providing funding. The landowners and managers at Swartdam are thanked for allowing access to the farm to conduct the field work. Many thanks go to the West Coast District Municipality Fire \& Rescue Services and the Greater Cederberg Fire Protection Association for conducting the prescribed burn at the study site. Special thanks go to Fiona Hellmann and Sybil Majo for fieldwork assistance, to Alistair Galloway for assistance with the soil seed bank experiment, to Nick Helme and JanHendrik Keet for helping with some of the species identifications and to Vivienne Williams for advice on some of the data analyses. The South African Weather Service is thanked for providing climate data. Fieldwork was conducted under a CapeNature permit (Permit No. 0028-AAA043-00012).

\section{ORCID}

Stephen R. Cousins (iD http://orcid.org/0000-0001-9133-9306

\section{REFERENCES}

Badano, E. I., Cavieres, L. A., Molina-Montenegro, M. A., \& Quiroz, C. L. (2005). Slope aspect influences plant association patterns in the Mediterranean matorral of central Chile. Journal of Arid Environments, 62, 93-108. https://doi.org/10.1016/j.jaridenv.2004.10.012

Baskin, J. M., Davis, B. H., Baskin, C. C., Gleason, S. M., \& Cordell, S. (2004). Physical dormancy in seeds of Dodonaea viscosa (Sapindales, Sapindaceae) from Hawaii. Seed Science Research, 14, 81-90.

Bell, D. T., Plummer, J. A., \& Taylor, S. K. (1993). Seed germination ecology in southwestern western Australia. Botanical Review, 59, 24-73. https:// doi.org/10.1007/BF02856612

Bergh, N. G., Verboom, G. A., Rouget, M., \& Cowling, R. M. (2014). Vegetation types of the Greater Cape Floristic Region. In N. Allsopp, J. F. Colville \& G. A. Verboom (Eds.), Fynbos: Ecology, evolution, and conservation of a megadiverse region (pp. 1-25). New York, NY: Oxford University Press.

Bond, W. J., \& Van Wilgen, B. W. (1996). Fire and plants. London, UK: Chapman \& Hall. https://doi.org/10.1007/978-94-009-1499-5

Bossuyt, B., \& Honnay, O. (2008). Can the seed bank be used for ecological restoration? An overview of seed bank characteristics in European communities. Journal of Vegetation Science, 19, 875-884. https://doi. org/10.3170/2008-8-18462

Brown, N. A. C. (1993). Promotion of germination of fynbos seeds by plant-derived smoke. New Phytologist, 123, 575-583. https://doi. org/10.1111/j.1469-8137.1993.tb03770.x

Cocks, M. P., \& Stock, W. D. (1997). Heat stimulated germination in relation to seed characteristics in fynbos legumes of the Western Cape Province, South Africa. South African Journal of Botany, 63, 129-132. https://doi.org/10.1016/S0254-6299(15)30724-9

Cowan, O. S., \& Anderson, P. M. L. (2014). The Peninsula Shale Renosterveld of Devil's Peak, Western Cape: A study into the vegetation and seedbank with a view toward potential restoration. South African Journal of Botany, 95, 135-145. https://doi.org/10.1016/j.sajb.2014.09.003

Cramer, M. D., Von Holdt, J., Khomo, L., \& Midgley, J. J. (2016). Evidence for aeolian origins of heuweltjies from buried gravel layers. South African Journal of Science, 112, 1-10.

Curtis, O. E. (2013). Management of critically endangered renosterveld fragments in the Overberg, South Africa. Unpublished PhD Thesis. University of Cape Town, ZA.

De Lange, J. H., \& Boucher, C. (1990). Autecological studies on Audouinia capitata (Bruniaceae). I. Plant-derived smoke as a seed germination cue. South African Journal of Botany, 56, 700-703. https://doi.org/10.1016/ S0254-6299(16)31009-2

Dessaint, F., Chadoeuf, R., \& Barralis, G. (1997). Nine years' soil seed bank and weed vegetation relationships in an arable field without weed control. Journal of Applied Ecology, 34, 123-130. https://doi. org $/ 10.2307 / 2404853$

Figueroa,J.A., Teillier,S., \& Jaksic, F.M.(2004). Composition, sizeand dynamics of the seed bank in a Mediterranean shrubland of Chile. Austral Ecology, 29, 574-584. https://doi.org/10.1111/j.1442-9993.2004.01392.x

Hall, S. A., Newton, R. J., Holmes, P. M., Gaertner, M., \& Esler, K. J. (2016). Heat and smoke pre-treatment of seeds to improve restoration of an endangered Mediterranean climate vegetation type. Austral Ecology, 42(3), 354-366.

Hassen, A., Pieterse, P. A., \& Rethman, N. F. G. (2004). Effect of pre-planting seed treatment on dormancy breaking and germination of Indigofera accessions. Tropical Grasslands, 38, 154-157.

Heelemann, S., Krug, C., Esler, K. J., Reisch, C., \& Poschlod, P. (2013). Soil seed banks of remnant and degraded Swartland Shale Renosterveld. 
Applied Vegetation Science, 16, 585-597. https://doi.org/10.1111/ avsc.12026

Herranz, J. M., Ferrandis, P., \& Martínez-Sánchez, J. J. (1998). Influence of heat on seed germination of seven Mediterranean Leguminosae species. Plant Ecology, 136, 95-103. https://doi. org/10.1023/A:1009702318641

Holmes, P. M., \& Cowling, R. M. (1997). Diversity, composition and guild structure relationships between soil-stored seed banks and mature vegetation in alien plant-invaded South African fynbos shrublands. Plant Ecology, 133, 107-122. https://doi.org/10.1023/A:100973402 6612

Holmes, P. M., \& Newton, R. J. (2004). Patterns of seed persistence in South African fynbos. Plant Ecology, 172, 143-158. https://doi. org/10.1023/B:VEGE.0000026035.73496.34

Hopfensperger, K. N. (2007). A review of similarity between seed bank and standing vegetation across ecosystems. Oikos, 116, 1438-1448. https://doi.org/10.1111/j.0030-1299.2007.15818.x

Jiménez, H. E., \& Armesto, J. J. (1992). Importance of the soil seed bank of disturbed sites in Chilean matorral in early secondary succession. Journal of Vegetation Science, 3, 579-586. https://doi. org/10.2307/3235824

Keeley, J. E. (1992). Demographic structure of California chaparral in the long-term absence of fire. Journal of Vegetation Science, 3, 79-90. https://doi.org/10.2307/3236001

Keeley, J. E., \& Bond, W. J. (1997). Convergent seed germination in South African fynbos and Californian chaparral. Plant Ecology, 133, 153-167. https://doi.org/10.1023/A:1009748603202

Keeley, J. E., Bond, W. J., Bradstock, R. A., Pausas, J. G., \& Rundel, P. W. (2012). Fire in Mediterranean ecosystems: Ecology, evolution and management. New York, NY: Cambridge University Press.

Keeley, J. E., Fotheringham, C. J., \& Baer-Keeley, M. (2005). Factors affecting plant diversity during post-fire recovery and succession of Mediterranean-climate shrublands in California, USA. Diversity and Distributions, 11,525-537.https://doi.org/10.1111/j.1366-9516.2005. 00200.x

Kemper, J., Cowling, R. M., \& Richardson, D. M. (1999). Fragmentation of South African renosterveld shrublands: Effects on plant community structure and conservation implications. Biological Conservation, 90, 103-111. https://doi.org/10.1016/S0006-3207(99)00021-X

Knight, R. S., Rebelo, A. G., \& Siegfried, W. R. (1989). Plant assemblages on mima-like earth mounds in the Clanwilliam district, South Africa. South African Journal of Botany, 55, 465-472. https://doi.org/10.1016/ S0254-6299(16)31143-7

Kraaij, T., \& Van Wilgen, B. W. (2014). Drivers, ecology, and management of fire in fynbos. In N. Allsopp, J. F. Colville, \& G. A. Verboom (Eds.), Fynbos: Ecology, evolution, and conservation of a megadiverse region (pp. 47-72). Oxford, UK: Oxford University Press. https://doi.org/10.1093/ acprof:oso/9780199679584.001.0001

Krug, R. M., Krug, C. B., Midoko Iponga, D., Walton, B., \& Milton, S. J. (2004). Reconstructing West Coast Renosterveld: past and present ecological processes in a Mediterranean shrubland of South Africa. Proceedings of the 10th MEDECOS conference, Rhodes, Greece.

Lamont, B. B., \& Downes, K. S. (2011). Fire-stimulated flowering among resprouters and geophytes in Australia and South Africa. Plant Ecology, 212, 2111-2125. https://doi.org/10.1007/s11258-011-9987-y

Le Maitre, D. C., \& Brown, P. J. (1992). Life cycles and fire-stimulated flowering in geophytes. In B. W. Van Wilgen, D. M. Richardson, F. J. Kruger \& H. J. Van Hensbergen (Eds.), Fire in South African mountain fynbos: Ecosystem, community and species response at Swartboskloof (pp. 145-160). Ecological Studies 93. Berlin, Germany: Springer. https://doi. org/10.1007/978-3-642-76174-4

Le Maitre, D. C., \& Midgley, J. J. (1992). Plant reproductive ecology. In R. M. Cowling (Ed.), The ecology of fynbos: Nutrients, fire and diversity. Cape Town, ZA, South Africa: Oxford University Press.
Le Roux, A. (2011). Brandvlei burns: A controlled burn in Breede Shale Renosterveld gives new life to plants, including the hitherto unknown Moraea vuvuzela. Veld \& Flora, 97, 16-18.

Levyns, M. R. (1956). Notes on the biology and distribution of the rhenoster bush. South African Journal of Science, 52, 141-144.

Manning, J., \& Goldlatt, P. (2012). Plants of the greater cape floristic region 1: The core cape flora. Pretoria, ZA, South Africa: Strelitzia 29. South African National Biodiversity Institute.

McDowell, C., \& Moll, E. (1992). The influence of agriculture on the decline of West Coast renosterveld, South-western Cape, South Africa. Journal of Environmental Management, 35, 173-192. https://doi.org/10.1016/ S0301-4797(05)80118-5

McIntyre, S., Lavorel, S., Landsberg, J., \& Forbes, T. D. A. (1999). Disturbance response in vegetation - towards a global perspective on functional traits. Journal of Vegetation Science, 10, 621-630. https://doi. org $/ 10.2307 / 3237077$

Midgley, G. F., \& Musil, C. F. (1990). Substrate effects of zoogenic soil mounds on vegetation composition in the Worcester-Robertson valley, Cape Province. South African Journal of Botany, 56, 158-166. https:// doi.org/10.1016/S0254-6299(16)31083-3

Moore, J. M., \& Picker, M. D. (1991). Heuweltjies (earth mounds) in the Clanwilliam district, Cape Province, South Africa: 4000-year-old termite nests. Oecologia, 86, 424-432. https://doi.org/10.1007/ BF00317612

Moreira, B., Tormo, J., Estrelles, E., \& Pausas, J. G. (2010). Disentangling the role of heat and smoke as germination cues in Mediterranean Basin flora. Annals of Botany, 105, 627-635. https://doi.org/10.1093/aob/ mcq017

Newton, I. P., \& Knight, R. S. (2005). The use of Landsat imagery for the identification of the remaining West Coast Renosterveld fragments, Western Cape Province, South Africa. South African Journal of Botany, 71, 67-75. https://doi.org/10.1016/S0254-6299(15)30151-4

Parker, V. T., \& Kelly, V. R. (1989). Seed banks in California chaparral and other Mediterranean climate shrublands. In M. A. Leck, V. T. Parker, \& R. L. Simpson (Eds.), Ecology of soil seed banks (pp. 231255). San Diego, CA: Academic Press. https://doi.org/10.1016/ B978-0-12-440405-2.50016-6

Pierce, S. M., Esler, K. J., \& Cowling, R. M. (1995). Smoke-induced germination of succulents (Mesembryanthemaceae) from fire-prone and fire-free habitats in South Africa. Oecologia, 102, 520-522. https://doi. org/10.1007/BF00341366

Procheş, S., Cowling, R. M., Goldblatt, P., Manning, J. C., \& Snijman, D. A. (2006). An overview of the Cape geophytes. Biological Journal of the Linnean Society, 87, 27-43. https://doi. org/10.1111/j.1095-8312.2006.00557.x

Radloff, F. G. T., Mucina, L., \& Snyman, D. (2014). The impact of native large herbivores and fire on the vegetation dynamics in the Cape renosterveld shrublands of South Africa: Insights from a 6-yr field experiment. Applied Vegetation Science, 17, 456-469. https://doi.org/10.1111/ avsc.12086

Rebelo, A. G., Boucher, C., Helme, N., Mucina, L., Rutherford, M. C., Smit, W. J., ... Scott, L. (2006). Fynbos biome. In L. Mucina, \& M. C. Rutherford (Eds.), The vegetation of South Africa, Lesotho and Swaziland (pp. 53219). Pretoria, ZA, South Africa: South African National Biodiversity Institute, Strelitzia.

Reyes, O., \& Trabaud, L. (2009). Germination behaviour of 14 Mediterranean species in relation to fire factors: Smoke and heat. Plant Ecology, 202, 113-121. https://doi.org/10.1007/s11258-008-9532-9

Rutherford, M. C., Powrie, L. W., Husted, L. B., \& Turner, R. C. (2011). Early post-fire plant succession in Peninsula Sandstone Fynbos: The first three years after disturbance. South African Journal of Botany, 77, 665-674. https://doi.org/10.1016/j.sajb.2011.02.002

Sternberg, M., \& Shoshany, M. (2001). Influence of slope aspect on Mediterranean woody formations: Comparison of a semiarid and 
an arid site in Israel. Ecological Research, 16, 335-345. https://doi. org/10.1046/j.1440-1703.2001.00393.x

Valbuena, L., \& Trabaud, L. (2001). Contribution of the soil seed bank to post-fire recovery of a heathland. Plant Ecology, 152, 175-183. https:// doi.org/10.1023/A:1011419721307

Van der Merwe, H., \& Van Rooyen, M. W. (2011). Vegetation trends following fire in the Roggeveld, Mountain Renosterveld, South Africa. South African Journal of Botany, 77, 127-136. https://doi.org/10.1016/j. sajb.2010.07.009

\section{SUPPORTING INFORMATION}

Additional Supporting Information may be found online in the supporting information tab for this article.

Appendix S1 Location of the study site
Appendix S2 Sampling design

Appendix S3 Standing vegetation and soil seed bank species list

Appendix S4 Diversity indices for the standing vegetation and soil seed banks

Appendix S5 Compositional similarity of the standing vegetation and soil seed banks

Appendix S6 Photographs of some of the burned and unburned standing vegetation sampled

How to cite this article: Cousins SR, Witkowski ETF, Esler KJ. Influence of fire on critically endangered Swartland Shale Renosterveld in the Cape Floristic Region. Appl Veg Sci. 2018;21:144-155. https://doi.org/10.1111/avsc.12348 